\title{
Language Edutainment Model In Reading Skill Based On Macapat Song For Blind Student
}

\author{
Sri Joeda Andajani ${ }^{\mathrm{a}}$, Pamuji ${ }^{\mathrm{b}}$ \\ Universitas Negeri Surabaya \\ Surabaya, Indonesia \\ sriandajani@unesa.ac.id
}

\begin{abstract}
The purpose of this research is to examine the effectiveness of language edutainment model of blind student in reading skill which is based on macapat song. This research is research and development (R\&D). The findings or phenomena in the field of small scale experiment are: 1) macapat song is difficult to pronounce, 2) it is difficult to remember the intonation, 3 ) it is not a common song, 4) it is rare to hear, and 5) it is difficult to learn the lyric. The direction of small scale basic experiment had been revised into learning innovation strategy. It is conducted by improving gamelan orchestra from pelog into gerongan. On the other hand, the big scale experiment of 10 blind students shows that 7 of them have excellent predicate, 1 student with enough, and 2 with minus predicate. It means that the effectiveness experiment of language edutainment shows the pleasing, inspiring, challenging, and motivating for blind learning of disabled student at junior high school.
\end{abstract}

Keywords—Language Edutainment; Reading Skill; Macapat

\section{INTRODUCTION}

Blind student has limited movement in their surroundings. It can be said that her/his daily activities do not work properly and smoothly. The introduction of the surrounding toward blind student is evidence that he/she can do the activities like normal people. According to Freire, et al. [1] learning activity of blind student is a behavior alteration process and happened as a educative result. It means that a certain person recognizes her/his duty in learning activity and the teacher also recognizes his/her own specific duty.

Reading skill development of blind student is directed into a macapat song comprehension that suits with his/her potential. The focus of it is to dig up her/his potential to be an entertainer. In this case, it is compatible with the development of disability or special education in entertainment sector. In that sector, a blind student needs full of support and opportunity from various sides such as, family, school, and citizen. The potential that is owned by blind student is reasonable to compete with normal student.

Dealing with that, fun teaching style is needed in order to make them to always happy and they can enjoy during learning. One of the teaching styles is by using language edutainment. In Indonesia, language means bahasa and edutainment is the short for "education and entertainment". It is therefore, the interrelatedness with the language edutainment definition is language learning with an entertainment unification to please the student, to make the learning process easier, to strengthen the brain memory, to activate the right brain, and to tighten social interaction.

According to Brown and Singhal [2], several kinds of edutainment are in term of talk show in radio and television, short story in radio and television, traditional entertainments such as wayang, quiz, fair, exposition, and game. One of these edutainments that appropriate for blind student is in term of challenging game, so that the students as a target language can stay longer in a certain place. Singhal and Rogers [3] stated that edutainment is an important thing to help learning development. Referring to natural characteristic of blind student who like to play and sing, the language edutainment model is developed. The function of the study is to motivate them with a pleasurable nuance and still keeping their focus on learning goals. It is expected that the learning process can increase their interest of the lessons. By the students' characteristic, there is such development of the learning concept of playing while studying. Song can create the body movement and even the acting. Bloom said that there are three aspects of learning domain; those are, cognitive, affective, and psychomotor. Edutainment learning is learning approach which is entertaining, fun and encouraging the student to love all the lessons. However, it is expected that it will be to change the lesson paradigm from a monotonous thing become an interesting thing and pleasurable for blind student.

The realization to answer an implementation above is by developing a reading skill based on macapat. Several learning aspects to develop the skill of, pronunciation, intonation, fluency and accuracy in reading macapat sentence can be performed through eductainment. This development research is directed to the strategy which is classified into four parts, 1) teachers' guide book, containing how to teach macapat 2) students' guide book, containing how to read and learn macapat in the form of Braille 3) macapat reading material in the form of Braille and compact disk of gamelan orchestra 4) evaluation instrument.

This research development is an alternative learning prototype that is more interested, effective and meaningful. Language edutainment is a learning model that is arranged and developed along with local quality. Macapat song is one of spoken Javanese traditions which grow and develop in 
society, especially Javanese people. It also contains of culture value which already exist in Javanese literary work. Javanese literary that was created by a poet generally has a glorious values doctrine such as, glorious attitude, moral, politeness, history, folklore, and so on.

Thus, by captivating oral singing tradition, the blind students will be able to recognize and grasp the value beyond literature which has positive vibe. Besides, the tradition in learning macapat means to inform the step or process of human life since him/her is born to die. Kinds of macapat song are Mijil, Maskumambang, Dandanggula, Asmaradana, Sinom, Durma, megatruh, pangkur, Pucung, and Kinanthi.

Based on the problem, it shows that macapat reading skill have been forgotten and disappeared among Javanese society. Related with that, it states a question on how the advisability of language edutainment in reading skill based on macapat song for junior high school disability's student.

There are two main purpose of this research development: In general, to produce the language edutainment model in reading skill based on macapat song for junior high school disability's student. In specific, to examine the effectiveness of language edutainment model in reading skill based on macapat song for junior high school disability's student.

\section{METHOD}

The research development (R\&D) approach is based on Dick, et al. [4]. This R \& D was used to plan to produce language edutainment prototype for blind student in reading skill. Afterwards, the result of product development is a learning procedure and process based on Gall, et al. [5] model.

The model in this research development used Gall, et al. [5] through several steps below:

- Doing the main field test or small scale

- Revise the product of implementation result of field test or small scale

- Doing a real field test or big scale

- Revise the final product

The subject of this research was blind student of disability junior high school in Surabaya, East Java. The first scheme below is the step of (R\&D) approach. 1:

The stage of product development is described in figure

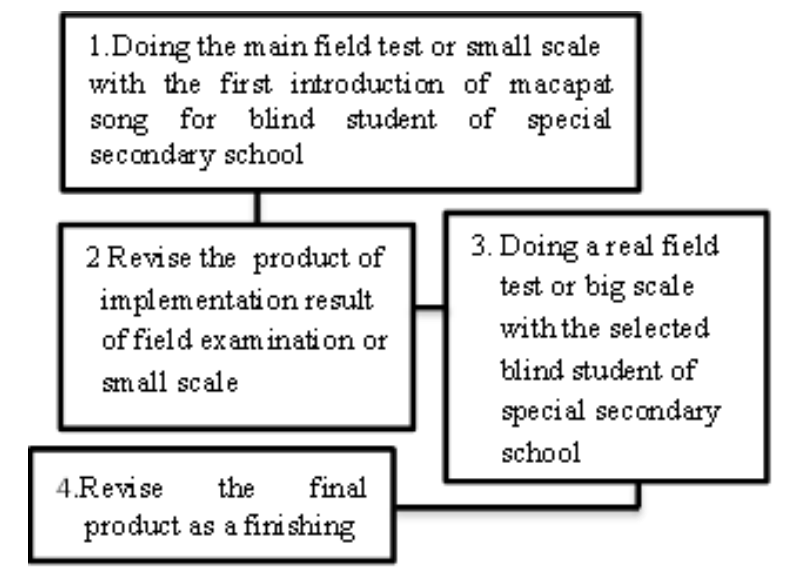

Fig. 1. The Stage of Product Development

Descriptive quantitative was applied in this study as a data analysis technique. Qualitative data was obtained from an expert test, while quantitative data was obtained from the field test. The following steps known as a cut-and-paste technique was applied to analyze the quantitative data [6]:

- Arrange the things that is not discussed,

- Identify the relevant thing with a question

- Provide a code for the result of relevant discussion with a question

- Replace irrelevant discussion result with the relevant one.

The reduction data was obtained through the test of small and big scale. The finding was the measurement of macapat reading skill with several components, such as pronunciation, intonation, fluency and lyric accuracy. The data verification or conclusion were done by obtaining the main data of field test in introducing macapat song to all blind student of VII, VIII and IX grader.

The following formula is a percentage technique to measure the advisability level:

$$
N A=\frac{n}{N} X 100
$$

Description:

$\mathrm{NA}=$ final score of analysis result

$\mathrm{N}=$ maximum score based on measured component

$\mathrm{n} \quad=$ total score of blind student

\section{RESUlt AND DisCUSSION}

\section{A. Field Test or Small Scale}

This part is based on main field test or small scale for the successes of 25 SMPLB's (Special Junior High School) student in reading skill comprehension of macapat song. The result of learning process is classified based on the percentage score in the form of table I below:

TABLE I. THE SMALL SCALE RESULT BASED ON THE PERCENTAGE SCORE OF SMPLB'S BLIND STUDENT IN MACAPAT READING SKILL

\begin{tabular}{|l|l|c|c|}
\hline No & Total student & Percentage & Predicate \\
\hline 1 & 7 blind students & $86 \%-100 \%$ & execelent \\
2 & 0 blind student & $71 \%-85 \%$ & good \\
3 & 1 blind student & $56 \%-70 \%$ & enough \\
4 & 2 blind students & $<55 \%$ & minus \\
\hline
\end{tabular}

According to percentage score above, it shows that 4 blind students have an excellent predicate, 9 of them have good predicate, 9 blind students have an enough predicate and 3 of them have minus predicate.

\section{B. Revise the Result of Field Main Test or Small Scale}

The students' complaint that occur spontaniously, was happened because he/she never hear the macapat lyric before. Besides, macapat song has been not taught before 
although it already exist in basic competency of SMPLB curriculum. However, blind student has an ability to show up her/his potential if he/she is given a chance to join the learning process. From that reason, it is expected that the edutainment process could be a great achievement of blind student in the future. In specific, the student has a good spoken ability. Therefore, blind student needs a pleasurable, variative, expressive and centerally services during learing implementation.

Based on the discussion and suggestion, the revision is performed regarding to gamelan orchestra in the form of gerongan by using senggakan as a music instrument. In its implementation, this macapat orchestra deliberately created with an East Java characteristic.

\section{Based on Real Field test or Big Scale}

This part focuses on the real field test or big scale for the successes of SMPLB's student in reading skill comprehension of macapat song. The result of learning process is classified based on the percentage score in the form of table II below:

TABLE II. THE BIG SCALE RESULT BASED ON THE PERCENTAGE SCORE OF SMPLB'S BLIND STUDENT IN MACAPAT READING SKILL COMPREHENSION

\begin{tabular}{|l|l|c|c|}
\hline No & Total student & Percentage & Predicate \\
\hline 1 & 7 blind students & $86 \%-100 \%$ & Execelent \\
2 & 0 blind student & $71 \%-85 \%$ & good \\
3 & 1 blind student & $56 \%-70 \%$ & enough \\
4 & 2 blind students & $<55 \%$ & minus \\
\hline
\end{tabular}

The assessment result of the table above show that seven blind students have an excellent predicate, only one have an enough predicate, while two of them have minus predicate. In this case, the revision of orchestra improvisation that have been done could make the student feels happy, inspired and motivated in learning macapat song.

\section{Revision of Real Field Test Result or Big Scale}

The finding of big scale test show that the student were excited to follow the course of macapat reading skill. By the new improvisation such as fun music instrument, it can strengthen the brain memory and social interaction among students. Because of that, language edutainment is really helpful to make the learning process easier. In connection to the whole finding, suggestion and discussion, research team stated that after the revision of big scale test, it should be conducted the application of collaborative concept. It was conducted in order to help the students who are lack in term of their singing skill, to motivate the student, and to learn with an entertainment and pleasurable nuance. The following is the alternative of Java music instrument as a innovation strategy:

- Start to choose the easy song of the difficult one

- Making a group that focus on the song

- Making a music instrument by using senggakan or penngiring
- Modified the song while sing

In the second year, the implementation of main field test or small scale, the revision of test result, real field test or big scale and the revision of final product were the achievement that desired as a language edurainment development. It means that it has the advisibility to be applied in the learning achievement. The connection between small scale test and task oriented based on student's work shows the various result of macapat song comprehension. The level of effectiveness of small scale result shows the finding that appear from the student complaint. They are stated as follow:

- Macapat song is difficult to pronounce

- Macapat song is difficult to remember in case of the intonation

- Macapat song is not a common song

- Macapat song is rare to hear

- The lyric of macapat song is difficult to understand

The situation above can be described into an assessment of student score percentage. In percentage $(86 \%-100 \%)$ or 4 blind students have an execelent predicate, in $(71 \%-85 \%)$ or 9 of them have good predicate, in $(56 \%-70 \%)$ or 9 blind students have an enough predicate and in $(<55 \%)$ or 3 of them have minus predicate.

Based on the result of small scale test, reviewed product development is needed in order to do a revision. Dealing with music instrument, the revision focuses on the language edutainment. It means that learning the language with an entertainment unification is to please student, to make the learning process easier, to strengthen the brain memory, to activate the right brain, and to tighten social interaction. The music instrument reference should be focused on the learning goal. Like what Savidis, et al. [7] said that entertainment as an important alternative functions to help learning development.

Refer to natural characteristic of blind student who like to play and sing, language edutainment model is needed to develop the study with a pleasurable nuance and focusededucation on learning goals. It is expected that the learning process will be able to increase students' interest toward lessons.

The realization of big scale result was presented on the assessment of student score in term of their comprehension. In percentage $(86 \%-100 \%)$ or as many as 7 blind students have an excellent predicate, in $(56 \%-70 \%)$ or as many as 1 blind student has an enough predicate and in $(<55 \%)$ or as many as 2 of them have minus predicate. In this case, the direction of small scale basic experiment had been revised into learning innovation strategy. It was conducted by improving gamelan orchestra from pelog into gerongan. The implementation of improvisation shows that the student was happy, inspired, challenged, and motivated during learning process. From these strategy, it can be said that teaching an appropriate lesson is the best strategy to develop SMPLB's student potential. The following aspects 
are the construction of language edutainment model based on macapat:

- Educate and entertain

- Using an entertaining media

- Create a pleasure

- Increase motivation

- Create creativity

Based on the result of big and small scale test, it shows that blind students have their own different potential. Naturally, play and sing can strengthen their character. It was shown from the various result, especially on the pronunciation, intonation, fluency and macapat reading accuracy. According to Meece, et al. [8] there are two evaluation, these are task oriented and ego oriented. Task oriented focuses on the student ability itself while ego oriented is the evaluation to see the students' ability and to compare it between one and the other in one class.

The successes of blind student in singing macapat has been presented through the performance from its characteristic. An effectiveness realization was obtained through the scale test for the behavior alteration during performance. Afterwards, the result of test was presented that a blind student has such intelligence development and it proofs that the student has an ability like normal people. Besides, blind students can execute their daily activities normally like common people. In the other side, one thing that should be considered to the blind student is an actualization of his/her vocal potential. An opportunity including adequate media is an essential thing to support the student in raising good achievement in the future. For blind students, various activities like creativity development is one of the self actualization which is suitable with their own ability. Macapat reading skill is a form of entertainment education in language section. Macapat learning as one of the Javanese lesson competency that need to be taught by using reading skill.

Reading skill can be seen as a process of "top down", it means that the reader use the information, idea or belief to understand the text. When the students start to suspect the text meaning, they try to use the knowledge of vocabulary, sintax, and discourse to understand the text. The reader uses both strategy based on (down-top) and (top-down)

Macapat is an abbreviation form phrase maca-pat-lagu which means "sing the four tone". It is also kind of traditional song or poetry. In each stanza of macapat song there is a sentence line named gatra. Each gatra has a number of syllables named guru wilangan, and ended the sound of last rhyme named guru lagu. Reading macapat depends on the nature of text that told. It is like the total of different padha per pupuh depending on the total text that is used in its song. Every padha is divided into lyric and gatra. Afterwards, each lyric or gatra is divided again into syllable or wanda. In conclusion, each gatra has a number of constant syllable and ended as vocal.
The connection between macapat reading skill and blind student characteristic is described as an action of understanding the text meaning with the knowledge that bears by each student. Besides, reading skill is a process to build new knowledge based on an existing knowledge. It means that the meaning of reading text is created through the interaction between text and reader. According to Salmani and Jaafari [9], an efficient reader relies on the linguistic data tabulation from text which is mapped into schematic that owned by blind student. Regarding to blind students' characteristic who have vocal management, in the case of reading skill, it needs comprehension of every single text about the content and type of macapat. Specifically, the reader in doing their reading cannot be separate the amount of text structure in the text. Thus, in learning process of singing macapat, blind student needs correct reading strategy which is suitable with its braille characteristic.

Creativity realization of language edutainment development to reading skill with macapat and blind students characteristic needs awareness and comprehension also motivation as the main modal in delivering the content. This refers to the statement that every macapat song has different characteristic and type from other songs since characteristic determines the beauty of the song. Thus, the implementation of language edutainment model to strengthen reading skill based on macapat on blind students as the picture of skill in applying macapat reading method correctly is suitable with vocal rhyme of gamelan that suits to Eastern Javanese culture. Gamelan music arrangement (gerongan) as one of the implementation methods of language edutainment for reading skill is based on macapat for blind students.

Regarding to blind students, gerongan music of Eastern Javanese culture has exciting and inspiring tone in order to grow a willing to study the macapat song as traditional culture of Indonesia. Meanwhile, in the learning reading of macapat, the manifestation is on the coherence, rhyme and in step for the beauty of articulation, intonation, fluency and accurateness in singing. Conditioning this learning is to identify the equality and difference of tone or rhyme from every aesthetic of saying or meaning of the text. So that, in order to release language edutainment model for reading skill which is based on macapat on blind student, there must be such need to appeal education service for blind student who need special setting in learning. They are stated as in the following;

- The use of language in learning

- Placement system or sitting arrangement in the class

- Availability of special program for traditional art skill

- The scale of mental development in showing own culture

- Handiness orientation in learning environment.

- Performance 
- Repetition in learning acquisition

\section{CONCLUSION}

In general, the purpose of this research is to produce the language edutainment model in reading skill based on macapat song for junior high school disability's student. There are some conclusion, they are: a) an efectiveness realization was obtained through the scale test for the behavior alteration during performance, b) the result of the test was presented that a blind student bears intelligence development and it proofs that the student has an ability like common normal people, c) blind students can execute their daily activities normally like other common people, d) one thing that should be considered to the blind student is an actualization of his/her vocal potential. An opportunity including adequate media is an essential to support the student in raising good achievement in the future, especially to develop the nation cultural tradition.

\section{REFERENCES}

[1] A. P. Freire, F. Linhalis, S. L. Bianchini, R. P. Fortes, and C. P. Maria da Graça, "Revealing the whiteboard to blind students: An inclusive approach to provide mediation in synchronous e-learning activities," Computers \& Education, vol. 54, pp. 866-876, 2010.

[2] W. J. Brown and A. Singhal, "Entertainment-education media strategies for social change: Promises and problems," Mass Media Social Control and Social, pp. 263-280, 1999.

[3] A. Singhal and E. Rogers, Entertainment-education: A communication strategy for social change: Routledge, 2012.

[4] W. Dick, L. Carey, and J. O. Carey, "The systematic design of instruction," 2005

[5] M. D. Gall, W. R. Borg, and J. P. Gall, Educational research: An introduction: Longman Publishing, 1996.

[6] A. Burns, Collaborative action research for English language teachers: Ernst Klett Sprachen, 2003

[7] A. Savidis, D. Grammenos, and C. Stephanidis, "Developing inclusive e-learning and e-entertainment to effectively accommodate learning difficulties," Universal Access in the Information Society, vol. 5, pp. 401-419, 2007.

[8] J. L. Meece, P. C. Blumenfeld, and R. H. Hoyle, "Students' goal orientations and cognitive engagement in classroom activities," Journal of educational psychology, vol. 80, p. 514, 1988.

[9] H. Salmani and M. Jaafari, "The Role of Motivational Strategies in An Iranian Efl Senior High Schoollearning Context," Journal of Fundamental and Applied Sciences, vol. 8, pp. 1618-1639, 2016. 